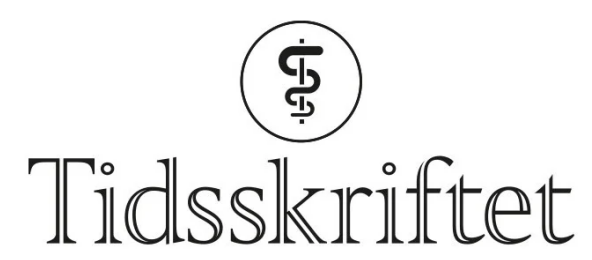

DEN NORSKE LEGEFORENING

\title{
Ungdom og kriser
}

\section{LEDER}

\section{KNUT-INGE KLEPP}

knut-inge.klepp@fhi.no

Knut-Inge Klepp er direktør for psykisk og fysisk helse ved Folkehelseinstituttet og professor ved Det medisinske fakultet, Universitetet i Oslo. Klepp har ledet og deltatt i en rekke EU-finansierte forskningsprosjekt og leder et stort prosjekt for å forebygge overvekt og fedme blant barn og unge (CO-CREATE).

Forfatteren har fylt ut ICMJE-skjemaet og oppgir ingen interessekonflikter.

\section{Hvilke erfaringer har ungdom gjort seg under koronapandemien?}

Covid-19-pandemien har synliggjort at smittevern kan ha andre konsekvenser enn bare smitteverneffekten. Mange har løftet fram de sosiale og psykiske belastningene som barn og unge utsettes for. Vi trenger kunnskap om ungdommers liv og hvordan disse påvirkes i kriser for å kunne iverksette og evaluere tiltak på tvers av sektorer lokalt og nasjonalt.

Å etablere en infrastruktur for overvåking og evaluering tar tid og kan ikke utsettes til krisen rammer. Data for krisehåndtering må basere seg på etablerte system for datainnhenting, både fra registre og befolkningsundersøkelser.

Ulset og medforfatteres artikkel som nå publiseres i Tidsskriftet (1), illustrerer dette. Ved å analysere data fra Ungdataundersøkelsen samlet inn blant norske skoleungdommer våren 2021, gir forfatterne et viktig innblikk i hvordan ungdom selv opplever å bli påvirket av pandemien (2).

Halvparten av deltakerne svarte at pandemien har påvirket livet deres delvis eller mye i negativ retning. Jenter, eldre ungdom, ungdom fra familier med lavere sosioøkonomisk status og ungdom fra kommuner med høy smitteforekomst oppga oftere negative erfaringer. Men bildet er ikke entydig. Én av fem oppga at pandemien hadde påvirket livet deres i positiv retning, ved at de for eksempel gjorde flere hyggelige ting med familien og at det var mindre stress i hverdagen (1). Resultatene underbygger funn fra annen forskning og supplerer denne ved at det er ungdommenes egne opplevelser av pandemien man har spurt om i Ungdata-undersøkelsen (3).

Funnene i Ulset og medarbeideres undersøkelse reiser en rekke nye spørsmål som er viktige for å kunne utforme nødvendige tiltak. Hvordan påvirker de opplevde negative konsekvensene ungdommen? Henger de negative konsekvensene sammen med utvikling av andre helseproblemer? Vedvarer problemene over tid? Hva karakteriserer de ungdommene som er mest utsatt eller som opplever positive endringer? 
Ulset og medforfattere peker på behovet for prospektive studier for å få kunnskap om mulige kausale effekter av pandemien (1ํ). Ettersom Ungdata-undersøkelsene gjennomføres anonymt, er det ikke mulig å følge deltakerne over tid eller kople til andre datakilder som kan si noe om individenes utvikling over tid. Der har store, pågående prospektive kohortstudier, som den norske Mor, far og barn-undersøkelsen (MoBa), sin styrke. I disse kan oppdatert informasjon som hentes inn om smittesymptomer, helseatferd eller psykisk helse, koples til store mengder allerede innsamlede data, inkludert helseregistre og biologiske data (4).

Folkehelseinstituttet har i samarbeid med fylkeskommunene etablert regelmessige fylkeshelseundersøkelser der store, representative utvalg av voksne (18 år og eldre) inviteres til å delta (5). Her åpner samtykket for at deltakeren kan kontaktes igjen og at svarene kan koples til data fra ulike registre og helseundersøkelser. Det er gjennomført flere undersøkelser om blant annet endring i livskvalitet under pandemien, etterlevelse av offisielle smittevernråd samt psykiske plager (므). Store utvalg gjør det mulig å studere effekten av konkrete forebyggende tiltak på kommunenivå dersom disse planlegges slik at man kan sammenlikne før og etter innføring av tiltak og på tvers av kommuner med og uten aktuelle tiltak.

\section{"Covid-19-pandemien har synliggjort behovet for et kunnskapssystem som kan gi oss nødvendige planleggings- og styringsdata $i$ en krisesituasjon»}

I tillegg til styrket utnyttelse av nasjonale data vil økt bruk av internasjonale, sammenliknende studier bidra til å styrke kunnskapsgrunnlaget for tiltak rettet mot ungdom. Internasjonale studier, blant annet i regi av Verdens helseorganisasjon, gjennomføres regelmessig og har utviklet kvalitetssikrede spørreskjemaer oversatt til ulike språk. Disse vil kunne tilpasses og skaleres i krisesituasjoner. Et pågående EU-prosjekt, COCREATE, har som hovedmål å bidra til å kople den infrastrukturen de store pågående europeiske ungdomsundersøkelsene representerer til databaser over tiltak gjennomført i ulike land (7.). På samme måte som lokale «naturlige eksperimenter» i norske kommuner kan og må effektevalueres, vil økt koordinering og bruk av internasjonale, sammenliknende studier gjøre det mulig å evaluere nasjonale tiltak på en raskere og mer solid måte enn i dag.

Covid-19-pandemien har synliggjort behovet for et kunnskapssystem som kan gi oss nødvendige planleggings- og styringsdata i en krisesituasjon. Beredskapsregisteret har vist oss hvordan data fra helseregistrene kan koples og komme til nytte raskt og sikkert (ㅁ). Tilsvarende er det behov for å gjennomgå hvordan helseundersøkelser organiseres, finansieres og koordineres for å være anvendelige i kriser. Undersøkelser som dem utført av Ungdata, danner et godt utgangspunkt for å skaffe oppdaterte data, også om effekt av tiltak. $\emptyset \mathrm{kt}$ bruk av samtykke blant eldre ungdom med samtykkekompetanse, rask kopling til andre datakilder, forutsigbar finansiering, $\varnothing \mathrm{kt}$ analysekapasitet og tydeligere koordinering må til for å lykkes.

\section{LITTERATUR}

1. Ulset VS, Bakken A, von Soest T. Ungdoms opplevelser av konsekvenser av pandemien etter ett år med covid-19-restriksjoner. Tidsskr Nor Legeforen 2021; 141. doi: 10.4045/tidsskr.21.0335. [CrossRef]

2. Ungdata. https://www.ungdata.no/ Lest 8.9.2021. 
3. Nøkleby H, Borge TC, Johansen TB. Konsekvenser av covid-19- pandemien for barn og unges liv og psykiske helse: oppdatering av en hurtigoversikt. Oslo: Folkehelseinstituttet, 2021.

https://www.fhi.no/publ/2021/konsekvenser-av-covid-19-pandemien-for-barn-og-unges-liv-ogpsykiske-helse/ Lest 8.9.2021.

4. Den norske mor, far og barn-unders $\emptyset$ kelsen (MoBa). https://www.fhi.no/studier/moba/ Lest 8.9.2021.

5. Folkehelseinstituttet. Fylkeshelseundersøkelser.

https://www.fhi.no/div/helseundersokelser/fylkeshelseundersokelser/ Lest 8.9.2021.

6. Aarø LE, Vedaa $\emptyset$, Bruun T et al. Koronaatferd og landbakgrunn i fire fylker. Rapport. Oslo: Folkehelseinstituttet, 2021. https://www.fhi.no/nyheter/2021/ny-rapport-koronaatferd-oglandbakgrunn-i-fire-fylker/ Lest 8.9.2021.

7. Folkehelseinstituttet. CO-CREATE. https://www.fhi.no/en/studies/co-create/ Lest 8.9.2021.

8. Folkehelseinstituttet. Beredskapsregisteret for covid-19. https://www.fhi.no/sv/smittsommesykdommer/corona/norsk-beredskapsregister-for-covid-19/ Lest 8.9.2021.

Publisert: 27. september 2021. Tidsskr Nor Legeforen. DOI: 10.4045/tidsskr.21.0637

(C) Tidsskrift for Den norske legeforening 2023. Lastet ned fra tidsskriftet.no 26. april 2023. 